\title{
Labor Markets and Capital Tax Competition
}

\author{
Thomas Eichner \\ Thorsten Upmann
}

CESIFO WORKING PAPER No. 3099

CATEgory 1: Public Finance

JUNE 2010
An electronic version of the paper may be downloaded
- from the SSRN website: Www.SSRN.com
- from the RePEc website: $\quad$ www.RePEc.org
- from the CESifo website: www.CESifo-group.org/wp




\title{
Labor Markets and Capital Tax Competition
}

\begin{abstract}
Ogawa et al. (2006) analyze capital tax competition in a fixed-wage approach and show that the original results of Zodrow and Mieszkowski (1986) are not preserved in the presence of unemployment. In the present paper we challenge this view and investigate capital tax competition for some arbitrary institutional setting of the labor market. We find that if the labor market is characterized by some efficient bargaining solution, the results of Zodrow and Mieszkowski (1986) are preserved.
\end{abstract}

JEL-Code: H21, J51.

Keywords: capital tax competition, unemployment, efficient bargains.

\author{
Thomas Eichner \\ Department of Economics \\ University of Hagen \\ Universitätsstrasse 41 \\ 58097 Hagen \\ Germany \\ Thomas.Eichner@FernUni-Hagen.de
}

\author{
Thorsten Upmann \\ University Duisburg-Essen \\ Mercator School of Management \\ Lotharstrasse 65 \\ 47057 Duisburg \\ Germany \\ Thorsten.Upmann@uni-duisburg-essen.de
}

May 4, 2010 


\section{Introduction}

Recently Ogawa et al. (2006), hereafter OST, analyze capital tax competition within the basic model of Zodrow and Mieszkowski (1986), hereafter ZM, in the presence of unemployment. Using a fixed-wage model OST derive the following results: (i) when head taxes on immobile residents are available, the optimal capital tax rate is generically not zero, and (ii) when restrictions are imposed on head taxes, capital tax competition may result in overprovision of public goods. In addition, OST point out that increases in the capital tax rate affect employment, which is the driving force for the above mentioned results. Clearly, employment effects are absent in ZM, who consider a locally fixed factor which can be interpreted as land or labor. To sum up, OST find that the results of ZM are not preserved when introducing labor market imperfections.

Since OST use a fixed-wage approach it is important to scrutinize the robustness of their results with respect to modifications of the institutional setting on the labor market. OST write in their concluding remarks: "Alternative models, such as the unemployment models of efficiency wage, trade union, and job research, can be presented. However, these extensions will show that, even though we allow for several types of labor market imperfections, the propositions in the paper are preserved."

The present paper challenges this view. To this end we use the ZM model and introduce unemployment in a general fashion. Residents either are employed and receive wage income, or they are unemployed and enjoy full leisure time. The wage rate and the employment level are determined on the labor market, which in order to achieve at greatest generality is left unspecified. In this framework, the labor market may be distorted, driving a wedge between marginal productivity of labor and the reservation wage rate, which reflects the social opportunity cost of labor. It is shown that the capital tax rate is used to internalize the distortion on the labor market and, in this way, indirectly does the job of a labor tax. However, for some institutional settings of the labor market, this distortion may be absent, e.g. if employment is chosen such that the marginal productivity of labor is equal to the reservation wage rate. In this case we get the original results of ZM: (i) the optimal capital tax rate is zero when head taxes are available, (ii) capital tax competition results in an underprovision of public goods when governments are 
restricted from using head taxes. More specifically, we prove that the labor-market effect vanishes in the capital-tax formula if the wage rate and the employment level are negotiated according to some efficient solution concept, that is, if the outcome lies on the (vertical) Pareto curve. Examples include the Nash bargaining solution (Nash 1950), the Kalai-Smorodinsky solution (Kalai and Smorodinsky 1975), the egalitarian solution (Kalai 1977) and the equal loss solution (Chun 1988).

\section{Capital tax competition}

Consider $n$ identical jurisdictions. In each jurisdiction, whose economy is small relative to the rest of the world, a representative consumer is endowed with capital $\bar{k}$, and with $t$ units of time. Capital is perfectly mobile, while labor is assumed to be immobile. The consumer's preferences are represented by the utility function ${ }^{1}$

$$
u=U(x, f, g)=x+\tilde{U}(f)+V(g) .
$$

Equation (1) presupposes that the consumer derives utility from private consumption, $x$, from public-good consumption, $g$, and from leisure time, $f$. The sub-utility functions $\tilde{U}$ and $V$ are increasing and strictly concave in their arguments.

We normalize the mass of consumers to unity and distinguish two types of consumers: employed workers and unemployed workers. Both types of consumers inelastically supply $\bar{\ell}$ units of labor, but only employed workers have the luck to get a job. For institutional reasons, consumers can only obtain full employment contracts so that they are either unemployed with leisure time $f=t$, or have a fulltime job with leisure time $f=t-\bar{\ell}$. Accordingly, an employed worker receives the wage rate $w$, whereas each unemployed worker does not receive any labor income. Households are only willing to give up leisure if $w+\tilde{U}(t-\ell)>\tilde{U}(t)$. Setting $\tilde{U}(t-\bar{\ell}) \equiv 0, \tilde{U}(t) \equiv \bar{u}$ and $\bar{\ell} \equiv 1$, consumers are indifferent between working and being unemployed at the reservation wage rate $\bar{w} \equiv \bar{u}$. Next to labor consumers have additional sources of income. They receive part of their income in the form of untaxed dividends paid out of firms' profits, $\pi$, (to be specified below) and in the form of capital income. With this information the budget constraints and the utility

\footnotetext{
${ }^{1}$ Upper case letters denote functions and subscripts attached to them indicate first partial derivatives.
} 
of the employed $(e)$ and unemployed $(u)$ workers are given by

$$
\begin{aligned}
& x^{j}= \begin{cases}\pi+w+r \bar{k}-h & \text { if } \quad j=1, \\
\pi+r \bar{k}-h & \text { if } j=u,\end{cases} \\
& u^{j}= \begin{cases}x^{j}+V(g) & \text { if } j=e, \\
x^{j}+\bar{u}+V(g) & \text { if } j=u,\end{cases}
\end{aligned}
$$

where $h$ denotes a head tax, and $r$ the net return of capital.

In each jurisdiction firms use capital, $k$, and labor, $\ell$, to produce their output, $y$, according to the increasing and strictly concave production function $y=F(k, \ell)$. The price-taking firms face an output price equal to one, the wage rate $w$, the net return of capital $r$ and the (source-based) tax on capital $\tau$. Then profits are given by

$$
\pi=\Pi(k, \ell, w) \equiv F(k, \ell)-w \ell-(r+\tau) k
$$

Irrespective of the institutional setting of the labor market, we assume that firms equate the marginal productivity of capital to its cost

$$
F_{k}(k, \ell)=r+\tau
$$

Eq. (4) and the labor market mechanism, which for the purpose of generality is not specified here, determine the equilibrium values of capital, employment and the wage rate as function of the capital tax rate

$$
k=K(\tau), \quad \ell=L(\tau) \quad \text { and } \quad w=W(\tau)
$$

We assume that investments are decreasing in the capital tax rate while the signs of the derivatives $L_{\tau}$ and $W_{\tau}$ are left open. Since head taxes are non-distortionary, varying $h$ does not affect capital, employment and the wage rate.

Output can be transformed one-to-one into private consumption or into public consumption. The jurisdictional government finances the provision of the public good by means of the revenues from the head tax and the capital tax. Then the fiscal budget constraint reads as

$$
\tau k+h=g
$$


The jurisdictional government takes the net return of capital as given but realizes that the equilibrium variables depend on the capital tax rate according to eq. (5). It applies the utilitarian welfare function

$$
\ell U\left(x^{e}, f^{e}, g\right)+(1-\ell) U\left(x^{u}, f^{u}, g\right)
$$

where $\ell$ and $1-\ell$ are the shares of employed and unemployed workers, respectively. Inserting eqs. (1)-(3), (5), (6) in (7) the welfare function can be written as

$\Omega(\tau, h):=[1-L(\tau)] \bar{u}+r \bar{k}-h+F(K(\tau), L(\tau))-(r+\tau) K(\tau)+V(\tau K(\tau)+h)$.

Maximizing $\Omega$ with respect to $h$ and $\tau$ yields the first-order conditions

$$
\begin{aligned}
& \Omega_{h}=V_{g}-1=0, \\
& \Omega_{\tau}=\left(F_{\ell}-\bar{u}\right) L_{\tau}+\underbrace{\left[F_{k}-(r+\tau)\right]}_{=0, \text { from }(4)} K_{\tau}-K+\left(K+\tau K_{\tau}\right) V_{g}=0 .
\end{aligned}
$$

If head taxes are available the government can implement the efficient allocation of public goods, which is characterized by the well-known Samuelson rule $V_{g}=1$ (see eq. (8a)). Then rearranging eq. (8b) yields the optimal capital tax rate

$$
\tau=-\frac{\left(F_{\ell}-\bar{u}\right) L_{\tau}}{K_{\tau}}
$$

From eq. (9) we infer

Proposition 1. Suppose that jurisdictional governments can use a head tax on immobile residents. Then they choose a zero capital tax rate if and only if (i) $F_{\ell}=\bar{u}$ or (ii) $L_{\tau}=0$.

The optimal capital tax rate is used to reduce the distortion on the labor market. This distortion is reflected by the net marginal product of labor $F_{\ell}-\bar{u}$, i.e. the difference between the marginal product of labor and the reservation wage rate (social opportunity costs of labor). If $F_{\ell} \neq \bar{u}$ and the capital tax rate has employment effects $\left(L_{\tau} \neq 0\right)$, then the optimal capital tax rate is non-zero. E.g. suppose $L_{\tau}<0$ and $F_{\ell}>\bar{u}$, then the employment level is inefficiently low, i.e. below the competitive level $\ell^{C}$, defined by $F_{\ell}=w=\bar{u}$, and capital is subsidized to attract more capital in order to promote employment. The capital tax thus plays the role of an indirect labor tax which is absent in this framework. 
Proposition 1 reproduces the ZM results where employment effects of the tax rate are absent $\left(L_{\tau}=0\right)$ and, at the same time, extends their results to a perfectly competitive labor market. However, as will be shown below, there exist other institutional settings of the labor market, different from perfect competition, at which $F_{\ell}=\bar{u}$. Proposition 1 is also in accordance with OST who do not consider leisure and hence assume that the reservation wage is equal to zero. Hence, for $F_{\ell}>\bar{u} \equiv 0$ they get that the capital tax rate is zero if and only if $L_{\tau}=0$.

Next, we assume that head taxes are not at the governments' disposal. Rearranging eq. (8b) then yields

$$
V_{g}=\frac{1-\frac{1}{k}\left(F_{\ell}-\bar{u}\right) L_{\tau}}{1+\frac{\tau}{k} K_{\tau}}
$$

Eq. (10) represents the allocation rule for the local public good when it is exclusively financed by a distorting capital tax rate, and may be viewed as a generalization of ZM's public-good provision formula (eq. (8) therein). The second term of the denominator shows the capital tax rate effects on investments, while the second term of the numerator captures the capital tax rate effects on labor market distortions. Any increase in the capital tax rate induces capital to flight out of the jurisdiction. Throughout the rest of the paper we follow ZM and assume that governments act on the left-side of the Laffer curve, formally $1+\frac{\tau}{k} K_{\tau}>0 .{ }^{2}$ Then eq. (10) provides the following information

$$
V_{g} \lesseqgtr 1 \Longleftrightarrow \tau K_{\tau} \gtreqless-\left(F_{\ell}-\bar{u}\right) L_{\tau} .
$$

Recall that $K_{\tau}<0$ by assumption. In view of condition (11) we get $V_{g}>1$ and hence the original ZM underprovision result, if either the capital tax rate has no impact on employment $\left(L_{\tau}=0\right)$, or if $F_{\ell}=\bar{u}$ holds in the labor market equilibrium, that is if $\ell=\ell^{C}$, is satisfied. Clearly, according to condition (11) there are further constellations which are sufficient for underprovision. In contrast, overprovision of local public goods may only emerge, if $\left(F_{\ell}-\bar{u}\right) L_{\tau}>0$, that is, if the marginal productivity of labor is greater [smaller] than the wage rate and an increase in the capital tax rate fosters [hampers] employment. Our findings are summarized in

Proposition 2. Suppose that jurisdictional governments are restricted from using a head tax.

\footnotetext{
${ }^{2}$ Note, that this constitutes a necessary condition for the optimality of the tax rate and thus for an equilibrium.
} 
(a) Then the capital tax rate is inefficiently low and local public goods are underprovided if (i) $F_{\ell}=\bar{u}$ or (ii) $L_{\tau}=0$.

(b) A necessary condition for inefficiently high capital tax rates and the overprovision of public goods is $\left(F_{\ell}-\bar{u}\right) L_{\tau}>0$.

\section{Labor market scenarios}

A variety of different, plausible labor market institutions has been applied in the public economics literature, e.g. the monopolistic union (Richter and Schneider 2001), the right-to manage approach (Fuest and Huber 1999, Aronsson and Wehke 2008) in the context of optimal taxation of small economies, efficient Nash bargains (Bayındır-Upmann and Raith 2003, 2005) in the analysis of environmental tax reforms. Since the results of the capital tax competition hinge upon $\left(F_{\ell}-\bar{u}\right) L_{\tau}$, we now take a closer look at this term for these institutional settings of the labor market.

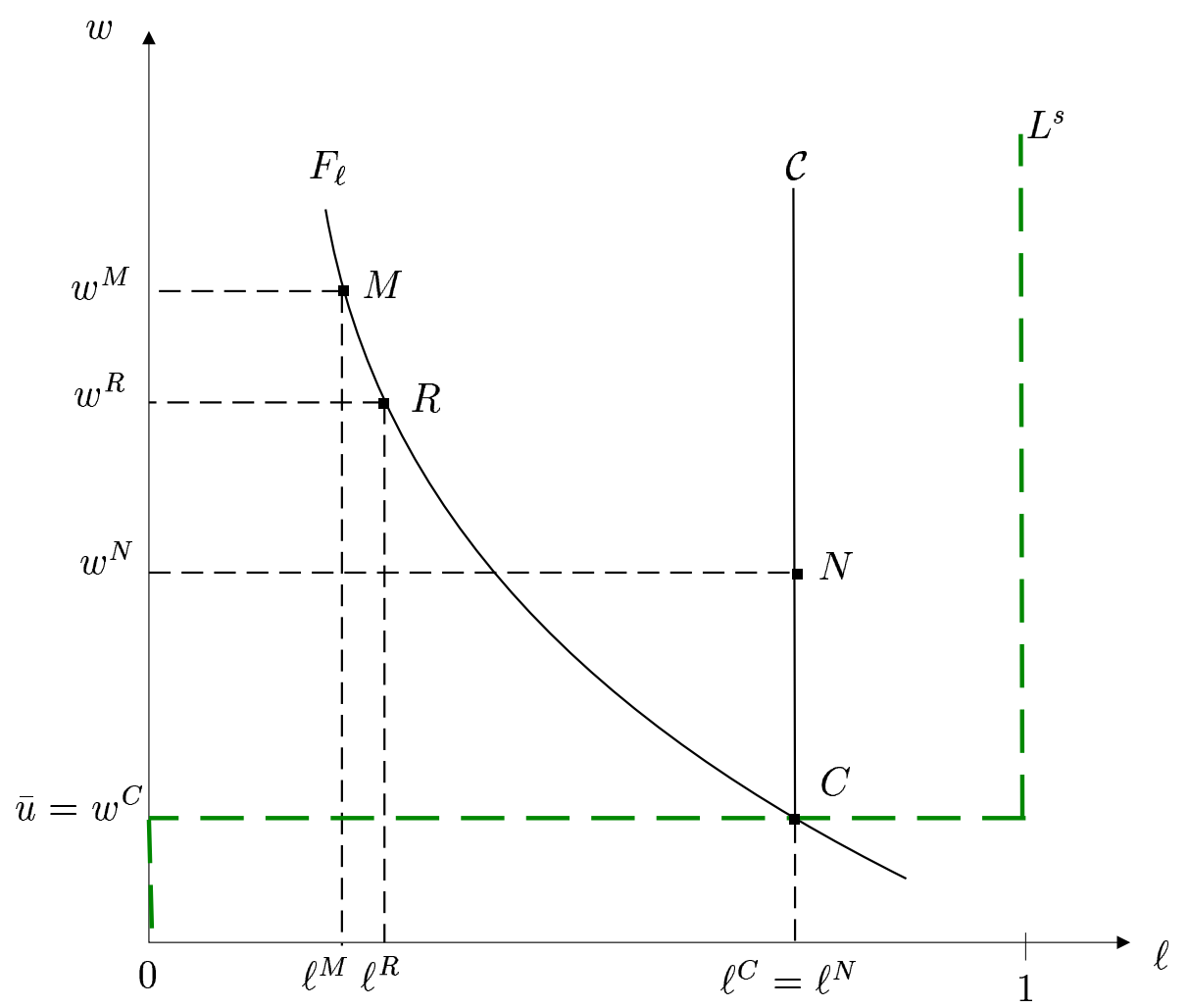

Figure 1: Different labor market scenarios

Figure 1 illustrates different labor market scenarios. $F_{\ell}$ represents the labor- 
demand curve, $L^{s}$ the labor-supply curve and $\mathcal{C}$ the contract curve. ${ }^{3}$ The intersection of the labor demand curve and the labor supply curve at point $C \equiv\left(\ell^{C}, w^{C}\right)$ determines the equilibrium of a perfectly competitive labor market. For the right-tomanage approach the equilibrium is at point $R$, and for the monopoly union the equilibrium is at point $M$, both of which lie on the labor demand curve. In comparison to the right-to-manage equilibrium, the monopoly union equilibrium is characterized by a higher wage rate but also by a lower employment level $\left(w^{M}>w^{R}, \ell^{M}<\ell^{R}\right)$. At these equilibria the net marginal productivity of labor is positive $\left(F_{\ell}-\bar{u}>0\right)$.

Any efficient bargaining outcome, however, lies on the contract curve, and thus leads to an employment level equal to $\ell^{C}$ and satisfies $F_{\ell}=\bar{u}$. This holds in particular for the frequently applied Nash solution (McDonald and Solow 1981, Creedy and McDonald 1991) ${ }^{4}$ the equilibrium outcome of which is depicted in Figure 1 as $N$. Hence we conclude ${ }^{5}$

Proposition 3. If the wage rate and the employment are determined by efficient bargains on the labor market, the ZM results are preserved.

Given the quasi-linear specification of the utility function (1), we are not aware of any labor market scenario at which $F_{\ell}<\bar{u}$, i.e. for which $\ell>\ell^{C}$ holds. Hence, if the comparative statics of the labor market equilibrium yields $L_{\tau}<0$, then there is no scope for overprovision of public goods (Proposition 2(a)). To put it differently, provided that $F_{\ell}>\bar{u}$ at an equilibrium of the labor market, a necessary condition for overprovision is that employment benefits from the tax-induced capital flight, i.e. $L_{\tau}>0$. But this condition to be fulfilled should be considered as an exception rather than as the rule.

\section{Concluding remarks}

The present paper aims at answering the question whether or not, and if so under which conditions, the results of ZM are preserved in the presence of unemployment.

\footnotetext{
${ }^{3}$ Note that for the quasi-linear specification of the utility function (1) the latter is vertical at $\ell^{C}$.

${ }^{4}$ Other well known efficient bargaining solutions are the Kalai-Smorodinsky solution (Kalai and Smorodinsky 1975), the egalitarian solution (Kalai 1977) or the equal loss solution (Chun 1988).

${ }^{5} \mathrm{~A}$ formal proof of Proposition 3 for Nash bargains can be found in the Appendix.
} 
To this end, we elaborate a generalized ZM framework which accommodates for any arbitrary labor market model, and show how the original ZM public-good provision formula (eq. (8) therein) may be generalized. While OST point out that this tax formula is not preserved in a fixed-wage labor market model, we show that the ZM formula continues to hold for any efficient labor market model. Closer inspection shows that in OST's fixed-wage approach the reservation wage is zero and hence the marginal productivity of labor exceeds the reservation wage. This is consistent with our result: Whenever labor differs from its competitive level and capital taxation causes employment effects, the public-good provision formula of ZM must be modified. This is in particular true for the right-to-manage model and the monopoly union. In contrast, if at some equilibrium of the labor market the marginal productivity of labor equals the reservation wage, which in our framework holds for any efficient bargaining solution, then the ZM formula and hence their economic results are strictly preserved.

It is worth mentioning that both our and OST's results depend on the quasilinear specification of the utility function. Allowing for more general utility functions the head tax and the capital tax rate cause distributional effects between employed and unemployed workers. However, since ZM who deal with a representative resident also abstract from distributional effects, our (and OST's) approach is fully in the spirit of ZM. Finally, incorporating distributional effects requires a modification of the Samuelson rule for the provision of public goods, even if head taxes were available. Nevertheless, augmenting our generalized tax competition model with involuntary unemployment by distributional considerations may constitute an interesting issue for future research.

\section{Appendix}

Proof of Proposition 3: At efficient Nash bargains the negotiations on the wage rate and employment take place simultaneously. On the supply side of the labor market there is an (encompassing) labor union which acts on behalf of all laborer's interests. On the demand side, the firms' interests are represented by an employers' association. While an employed worker obtains the wage rate $w$, an unemployed worker enjoys leisure time. When the labor union maximizes the sum of its members' 
utility its objective function may be written $\mathrm{as}^{6}$

$$
\Psi(w, \ell)=\ell w+(1-\ell) \bar{u}
$$

The employers' association aims to maximize the firms' profits. Applying the (asymmetric) Nash solution, the outcome of the bargaining process is obtained as the maximand of the Nash product:

$$
\Psi(w, \ell)^{\mu} \cdot \Pi(k, \ell, w)^{1-\mu}
$$

where $\mu \in[0,1]$. The bargaining parties take into account that once they have agreed on some tuple $(w, L)$ firms subsequently choose capital according to eq. (4), which determines the capital demand function $k=\kappa(\ell, \tau)$. Then maximizing (13) subject to $k=\kappa(\ell, \tau)$ yields the first-order conditions

$$
\begin{aligned}
\frac{w}{w-\bar{u}} & =\frac{w}{w-F_{\ell}(k, \ell)}, \\
w & =\mu \frac{F(k, \ell)-(r+\tau) k}{\ell}+(1-\mu) F_{\ell}(k, \ell) .
\end{aligned}
$$

Eq. (14a) constitutes the Pareto curve which is the set of all employment-wage combinations such that both parties' indifference curves are tangent to each other. Eq. (14b) is the Nash curve and determines the bargained wage as the weighted average of the average and marginal productivity of labor, net of the cost of other factors. From eq. (14a) we immediately infer $F_{\ell}=\bar{u}$.

\section{References}

Aronsson, T. and S. Wehke (2008): Public goods, unemployment and policy coordination, Regional Science and Urban Economics 38, 285-298.

Bayındır-Upmann, T. and M.G. Raith (2003): Should high-tax countries pursue revenue-neutral ecological tax reforms?, European Economic Review 47, 41-60.

Bayındır-Upmann, T. and M.G. Raith (2005): Unemployment and pollution - is one policy suited for two problems? Economic Record 81, 378-393.

\footnotetext{
${ }^{6}$ According to (12) the labor union is not fully rational in the sense that it does not take into account adjustments in profit income resulting from the bargaining process. Alternatively, we could add to employed workers and unemployed workers, say managers which are the firms' owners and receive the total profit income and capital income. Then (12) is a fully rational strategy of maximizing employed and unemployed workers private utility.
} 
Chun, Y. (1988): The equal-loss principle for bargaining problems, Economics Letters 26, 103-106.

Creedy, J. and J.M. McDonald (1991): Models of trade union behaviour: A synthesis, Economic Record 67, 346-359.

Fuest, C. and B. Huber (1999): Tax coordination and unemployment, International Tax and Public Finance 6, 7-26.

Kalai, E. (1977): Proportional solutions to bargaining situations: Interpersonal utility comparisons, Econometrica 45, 1623-1630.

Kalai, E. and M. Smorodinsky (1975): Other solutions to Nash's bargaining problem, Econometrica 43, 513-518.

McDonald, J.M. and R.M. Solow (1981): Wage bargaining and unemployment, American Economic Review 71, 896-908.

Nash, J.F. (1950): The bargaining problem, Econometrica 18, 155-162.

Ogawa, H., Sato, Y. and T. Tamai (2006): A note on unemployment and capital tax competition, Journal of Urban Economics 60, 350-356.

Richter, W.F. and K. Schneider (2001): Taxing mobile capital with labor market imperfections, International Tax and Public Finance 8, 245-262.

Zodrow, R.G. and P. Mieszkowski (1986): Pigou, property taxation, and the underprovision of local public goods, Journal of Urban Economics 19, 356-370. 


\section{CESifo Working Paper Series}

for full list see www.cesifo-group.org/wp

(address: Poschingerstr. 5, 81679 Munich, Germany, office@cesifo.de)

3037 Eric A. Hanushek and Ludger Woessmann, The Economics of International Differences in Educational Achievement, April 2010

3038 Frederick van der Ploeg, Aggressive Oil Extraction and Precautionary Saving: Coping with Volatility, April 2010

3039 Ainura Uzagalieva, Evžen Kočenda and Antonio Menezes, Technological Imitation and Innovation in New European Union Markets, April 2010

3040 Nicolas Sauter, Jan Walliser and Joachim Winter, Tax Incentives, Bequest Motives, and the Demand for Life Insurance: Evidence from two Natural Experiments in Germany, April 2010

3041 Matthias Wrede, Multinational Capital Structure and Tax Competition, April 2010

3042 Burkhard Heer and Alfred Maussner, A Note on the Computation of the Equity Premium and the Market Value of Firm Equity, April 2010

3043 Kristiina Huttunen, Jukka Pirttilä and Roope Uusitalo, The Employment Effects of Low-Wage Subsidies, May 2010

3044 Matthias Kalkuhl and Ottmar Edenhofer, Prices vs. Quantities and the Intertemporal Dynamics of the Climate Rent, May 2010

3045 Bruno S. Frey and Lasse Steiner, Pay as you Go: A New Proposal for Museum Pricing, May 2010

3046 Henning Bohn and Charles Stuart, Population under a Cap on Greenhouse Gas Emissions, May 2010

3047 Balázs Égert and Rafal Kierzenkowski, Exports and Property Prices in France: Are they Connected?, May 2010

3048 Thomas Eichner and Thorsten Upmann, Tax-Competition with Involuntary Unemployment, May 2010

3049 Taiji Furusawa, Kazumi Hori and Ian Wooton, A Race beyond the Bottom: The Nature of Bidding for a Firm, May 2010

3050 Xavier Vives, Competition and Stability in Banking, May 2010

3051 Thomas Aronsson and Erkki Koskela, Redistributive Income Taxation under Outsourcing and Foreign Direct Investment, May 2010 
3052 Michael Melvin and Duncan Shand, Active Currency Investing and Performance Benchmarks, May 2010

3053 Sören Blomquist and Laurent Simula, Marginal Deadweight Loss when the Income Tax is Nonlinear, May 2010

3054 Lukas Menkhoff, Carol L. Osler and Maik Schmeling, Limit-Order Submission Strategies under Asymmetric Information, May 2010

3055 M. Hashem Pesaran and Alexander Chudik, Econometric Analysis of High Dimensional VARs Featuring a Dominant Unit, May 2010

3056 Rabah Arezki and Frederick van der Ploeg, Do Natural Resources Depress Income Per Capita?, May 2010

3057 Joseph Plasmans and Ruslan Lukach, The Patterns of Inter-firm and Inter-industry Knowledge Flows in the Netherlands, May 2010

3058 Jenny E. Ligthart and Sebastian E. V. Werner, Has the Euro Affected the Choice of Invoicing Currency?, May 2010

3059 Håkan Selin, Marginal Tax Rates and Tax-Favoured Pension Savings of the SelfEmployed - Evidence from Sweden, May 2010

3060 Richard Cornes, Roger Hartley and Yuji Tamura, A New Approach to Solving Production-Appropriation Games with Many Heterogeneous Players, May 2010

3061 Ronald MacDonald and Flávio Vieira, A Panel Data Investigation of Real Exchange Rate Misalignment and Growth, May 2010

3062 Thomas Eichner and Rüdiger Pethig, Efficient Management of Insecure Fossil Fuel Imports through Taxing(!) Domestic Green Energy?, May 2010

3063 Vít Bubák, Evžen Kočenda and Filip Žikeš, Volatility Transmission in Emerging European Foreign Exchange Markets, May 2010

3064 Leonid V. Azarnert, Après nous le Déluge: Fertility and the Intensity of Struggle against Immigration, May 2010

3065 William E. Becker, William H. Greene and John J. Siegfried, Do Undergraduate Majors or Ph.D. Students Affect Faculty Size?, May 2010

3066 Johannes Becker, Strategic Trade Policy through the Tax System, May 2010

3067 Omer Biran and Françoise Forges, Core-stable Rings in Auctions with Independent Private Values, May 2010

3068 Torben M. Andersen, Why do Scandinavians Work?, May 2010 
3069 Andrey Launov and Klaus Wälde, Estimating Incentive and Welfare Effects of NonStationary Unemployment Benefits, May 2010

3070 Simon Gächter, Benedikt Herrmann and Christian Thöni, Culture and Cooperation, June 2010

3071 Mehmet Bac and Eren Inci, The Old-Boy Network and the Quality of Entrepreneurs, June 2010

3072 Krisztina Molnár and Sergio Santoro, Optimal Monetary Policy when Agents are Learning, June 2010

3073 Marcel Boyer and Donatella Porrini, Optimal Liability Sharing and Court Errors: An Exploratory Analysis, June 2010

3074 Guglielmo Maria Caporale, Roman Matousek and Chris Stewart, EU Banks Rating Assignments: Is there Heterogeneity between New and Old Member Countries? June 2010

3075 Assaf Razin and Efraim Sadka, Fiscal and Migration Competition, June 2010

3076 Shafik Hebous, Martin Ruf and Alfons Weichenrieder, The Effects of Taxation on the Location Decision of Multinational Firms: M\&A vs. Greenfield Investments, June 2010

3077 Alessandro Cigno, How to Deal with Covert Child Labour, and Give Children an Effective Education, in a Poor Developing Country: An Optimal Taxation Problem with Moral Hazard, June 2010

3078 Bruno S. Frey and Lasse Steiner, World Heritage List: Does it Make Sense?, June 2010

3079 Henning Bohn, The Economic Consequences of Rising U.S. Government Debt: Privileges at Risk, June 2010

3080 Rebeca Jiménez-Rodriguez, Amalia Morales-Zumaquero and Balázs Égert, The VARying Effect of Foreign Shocks in Central and Eastern Europe, June 2010

3081 Stephane Dees, M. Hashem Pesaran, L. Vanessa Smith and Ron P. Smith, Supply, Demand and Monetary Policy Shocks in a Multi-Country New Keynesian Model, June 2010

3082 Sara Amoroso, Peter Kort, Bertrand Melenberg, Joseph Plasmans and Mark Vancauteren, Firm Level Productivity under Imperfect Competition in Output and Labor Markets, June 2010

3083 Thomas Eichner and Rüdiger Pethig, International Carbon Emissions Trading and Strategic Incentives to Subsidize Green Energy, June 2010

3084 Henri Fraisse, Labour Disputes and the Game of Legal Representation, June 2010 
3085 Andrzej Baniak and Peter Grajzl, Interjurisdictional Linkages and the Scope for Interventionist Legal Harmonization, June 2010

3086 Oliver Falck and Ludger Woessmann, School Competition and Students' Entrepreneurial Intentions: International Evidence Using Historical Catholic Roots of Private Schooling, June 2010

3087 Bernd Hayo and Stefan Voigt, Determinants of Constitutional Change: Why do Countries Change their Form of Government?, June 2010

3088 Momi Dahan and Michel Strawczynski, Fiscal Rules and Composition Bias in OECD Countries, June 2010

3089 Marcel Fratzscher and Julien Reynaud, IMF Surveillance and Financial Markets - A Political Economy Analysis, June 2010

3090 Michel Beine, Elisabetta Lodigiani and Robert Vermeulen, Remittances and Financial Openness, June 2010

3091 Sebastian Kube and Christian Traxler, The Interaction of Legal and Social Norm Enforcement, June 2010

3092 Volker Grossmann, Thomas M. Steger and Timo Trimborn, Quantifying Optimal Growth Policy, June 2010

3093 Huw David Dixon, A Unified Framework for Using Micro-Data to Compare Dynamic Wage and Price Setting Models, June 2010

3094 Helmuth Cremer, Firouz Gahvari and Pierre Pestieau, Accidental Bequests: A Curse for the Rich and a Boon for the Poor, June 2010

3095 Frank Lichtenberg, The Contribution of Pharmaceutical Innovation to Longevity Growth in Germany and France, June 2010

3096 Simon P. Anderson, Øystein Foros and Hans Jarle Kind, Hotelling Competition with Multi-Purchasing: Time Magazine, Newsweek, or both?, June 2010

3097 Assar Lindbeck and Mats Persson, A Continuous Theory of Income Insurance, June 2010

3098 Thomas Moutos and Christos Tsitsikas, Whither Public Interest: The Case of Greece's Public Finance, June 2010

3099 Thomas Eichner and Thorsten Upmann, Labor Markets and Capital Tax Competition, June 2010 